\title{
PIRANTI LUNAK UNTUK ANALISIS BENTUK LENGKUNG GIGI DENGAN JARINGAN SARAF TIRUAN
}

\author{
M. Rahmat Widyanto ${ }^{1}$, Shinta Puspasari ${ }^{2}$ \\ ${ }^{1}$ Fakultas Ilmu Komputer, Universitas Indonesia, Kampus UI Depok, Jawa Barat \\ ${ }^{2}$ Program Studi Teknik Informatika, STMIK Multi Data Palembang \\ E-mail:widyanto@cs.ui.ac.id ${ }^{1}$,shinta@stmik-mdp.net ${ }^{2}$
}

\begin{abstract}
ABSTRAK: Dalam tulisan ini, dipaparkan hasil pengembangan system klasifikasi bentuk lengkung gigi berbasis algoritma propagasi balik jaringan saraf tiruan. Sejumlah fitur bentuk lengkung gigi dipilih sebagai input jaringan saraf tiruan berdasarkan hasil pengujian secara statistik terhadap variabel bentuk lengkung gigi. Piranti lunak dikembangkan terdiri dari sejumlah fitur yang digunakan untuk pengujian dan pelatihan JST, serta pengenalan bentuk lengkung berdasarkan parameter input yang diberikan oleh peng-guna. Eksperimen dilakukan terhadap data numerik hasil ekstraksi citra digital model cetakan lengkung gigi rahang atas sejumlah 190 orang pasien yang diambil secara acak. Citra lengkung gigi diperoleh dengan melakukan pemindaian terhadap model cetakan lengkung gigi tiga dimensi (3D) pasien ortodonti disejumlah klinik di Jakarta. Hasil uji coba menunjukkan bahwa 76,3158\% berhasil diklasifikasikan dengan benar oleh sistem berbasis JST tersebut. Ke depannya sistem akan dikembangkan lebih optimal sehingga dapat diguna- kan untuk mendukung perawatan ortodonti.
\end{abstract}

Kata kunci: jaringan saraf tiruan, bentuk lengkung gigi, analisis statistik

\begin{abstract}
In this paper, dental arch form classification system using back propagation algorithm is proposed. Some features of dental arch are selected for neural network input based on statistical analysis to dependent variables of dental arch. The system contains some features for training and testing the neural network, and for recognizing the arch form based on input parameters. The experiment uses randomly selected data set contains 190 numerical data of upper dental arch that are extracted from dental model images. The images were obtained by scanning the original 3D dental models of Indonesian patient that were collected from some orthodontic clinics in Jakarta. This experimental result shows that 76,3158\% of correctness in classifying the arch form can be reached by neural network system. The system can be applied for supporting the orthodontic treatment.
\end{abstract}

Keywords: neural network, dental arch form, statistical analysis

\section{PENDAHULUAN}

Salah satu organ yang berperan penting dalam menunjang metabolisme tubuh adalah gigi. Gigi yang tersusun pada tulang rahang membentuk struktur lengkung yang berbeda secara alamiah, dari segi ukuran maupun bentuk [1] yang dipengaruhi oleh bentuk tulang penyokong lengkung gigi, erupsi, dan kerusakan pada gigi [2]. Banyak permasalahan yang dapat terjadi pada struktur gigi baik secara fungsional maupun estetis. Semua permasalahan tersebut dapat diatasi dengan menjalani perawatan ortodonti. Perawatan ini dilakukan oleh seorang dokter gigi spesialis ortodonti. Contoh kasus yang banyak ditangani oleh ortodontis, yaitu masalah ketidakberaturan susunan gigi yang terjadi karena adanya ketidakseimbangan antara ukuran gigi dan ukuran rahang pasien yang mengakibatkan gigi tersusun dengan tidak rapi. Langkah-langkah perawatan untuk merapikan susunan gigi dilakukan berdasarkan diagnosis bentuk lengkung susunan gigi [3]. Bentuk lengkung gigi pasien ditentukan secara manual berdasarkan pengetahuan dan pengalaman ortodontis dengan cara melihat bentuk model cetakan gigi pasien. Untuk membuat model cetakan ini memerlukan biaya yang cukup besar serta memakan waktu, dan hasil perkiraan yang didapat bisa salah karena kelalaian manusia. Selain itu, bentuk lengkung susunan gigi, yaitu ovoid, tapered, dan square, memiliki kemiripan yang sangat tinggi sehingga sulit untuk dibedakan. Apalagi dengan tidak rapinya susunan gigi yang membuat bentuk lengkung menjadi makin tidak jelas.

Kemiripan bentuk ini sering kali menimbulkan perbedaan pendapat antar ortodontis saat menetapkan bentuk lengkung gigi seorang pasien. Kesalahan dalam menentukan bentuk lengkung akan berpengaruh pada keberhasilan dan kestabilan hasil perawatan [4].

Penelitian ini bertujuan mengembangkan sebuah piranti lunak pendukung perawatan ortodonti yang 
dapat mengklasifikasikan bentuk lengkung gigi pasien sebelum menjalani perawatan ortodonti. Sejumlah penelitian berkenaan dengan bentuk lengkung susunan gigi telah dilakukan. Dalam $[5,6]$ telah dicoba untuk merepresentasikan bentuk lengkung susunan gigi dalam bentuk kurva parabolik dengan teknik regresi kuadrat dan teknik hibrida antara regresi kuadrat dan k-nearest neighbor untuk memperjelas perbedaan antar kurva bentuk lengkung. Sebuah piranti lunak telah dikembangkan [7] dengan algoritma propagasi balik yang menggunakan sejumlah fitur lengkung gigi sebagai parameter masukan, namun hasil yang didapat belumlah optimal.

Sistem aplikasi telah dibangun berbasis jaringan saraf tiruan (JST) dengan algoritma propagasi balik, yang dapat mengklasifikasikan bentuk lengkung gigi pasien berdasarkan sejumlah nilai parameter lengkung gigi dimasukkan oleh pengguna. Fitur tersebut dipilih setelah terlebih dahulu dilakukan analisis secara statistik dengan uji ordered logistik untuk mengetahui variabel apa saja yang berpengaruh pada bentuk lengkung gigi.

Eksperimen dilakukan dengan menggunakan sebanyak 190 data gambar model cetakan gigi pasien orang Indonesia, sebelum dan sesudah menjalani perawatan ortodonti yang diambil dari sejumlah klinik dan praktik ortodontis di Jakarta. Sebaran sampel menurut jenis kelamin, yaitu 42 laki-laki $(22,1 \%)$ dan 148 perempuan $(77,9 \%)$. Dari data ini selanjutnya diekstrak sejumlah nilai parameter lengkung gigi yang diperlukan untuk masukan pada JST dengan melakukan pengukuran terhadap citra menggunakan sebuah piranti lunak. Data numerik hasil pengukuran tersebut selanjutnya digunakan untuk pelatihan dan pengujian pada JST. Sejumlah $40 \%$ dari data set digunakan untuk pelatihan, dan $60 \%$ digunakan untuk pengujian. Hasil penelitian menunjukkan angka keberhasilan yang cukup signifikan dalam menentukan bentuk lengkung gigi pasien sebelum menjalani perawatan ortodonti.

\section{LENGKUNG GIGI}

Susunan gigi pada tulang rahang membentuk sebuah lengkung yang memiliki bentuk dan ukuran yang berbeda untuk tiap individu. Lengkung gigi adalah garis yang menghubungkan titik kontak antar gigi [8]. Lengkung gigi didukung oleh setiap gigi yang terletak di dalam suatu basis tulang. Bentuk lengkung berdasarkan bagian anterior kurva dapat dikategorikan menjadi tiga, yaitu ovoid, tapered, dan square [9]. Ketiga bentuk lengkung tersebut memiliki kemiripan yang cukup tinggi sehingga sulit untuk dibedakan (Gambar 1).
Metode konvensional yang selama ini digunakan untuk menentukan bentuk lengkung gigi yaitu secara manual berdasarkan pengetahuan dan pengalaman seorang ortodontis. Bentuk lengkung gigi ditentukan dengan melihat model cetakan gigi yang sebelumnya telah dibuat. Pembuatan model ini sendiri memakan waktu yang lama serta biaya yang cukup besar, serta hasil prediksi yang diberikan memiliki kemungkinan kesalahan akibat faktor kelalaian dan kelemahan manusia. Padahal, penentuan bentuk lengkung gigi akan berpengaruh pada diagnosis dan rencana perawatan yang berdampak pada kesuksesan dan kestabilan hasil perawatan.

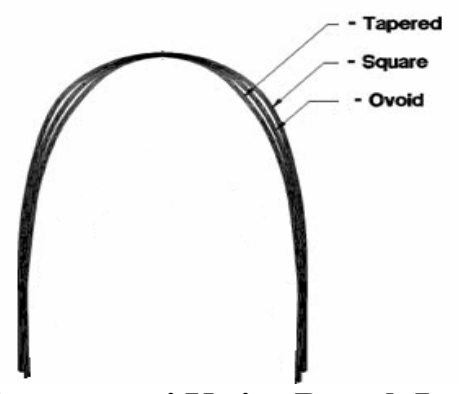

\section{Gambar 1. Representasi Ketiga Bentuk Lengkung Gigi}

Untuk menentukan bentuk lengkung gigi, perlu diperhatikan sejumlah parameter lengkung gigi. Parameter inilah yang nantinya akan digunakan sebagai fitur masukan bagi sistem JST yang akan dikembangkan. Gambar 2 adalah model cetakan gigi 2 (dua) dimensi yang mengilustrasikan sejumlah parameter lengkung gigi.

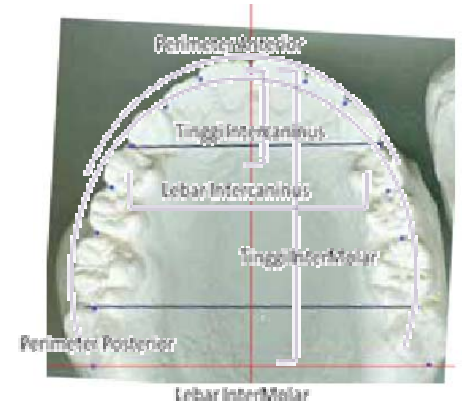

\section{Gambar 2. Model Cetakan Gigi}

Keterangan:

a. Lebar Interkaninus adalah jarak horizontal antara titik kontak distal kaninus kanan dan kaninus kiri.

b. Lebar Intermolar adalah jarak horizontal antara titik kontak distal molar pertama kanan dan kiri.

c. Tinggi kaninus adalah jarak vertikal antara titik kontak luar pertemuan insisivus pertama ke garis yang menghubungkan titik kontak distal kaninus kiri dan kanan. 
d. Tinggi Molar adalah jarak vertikal antara titik kontak luar pertemuan gigi insisivus pertama ke garis yang menghubungkan titik kontak distal gigi molar pertama kiri dan kanan.

e. Perimeter Anterior adalah jumlah total ukuran 6 (enam) gigi anterior

f. Perimeter Posterior adalah jumlah total 12 gigi anterior dan posterior.

\section{JARINGAN SARAF TIRUAN PROPAGASI BALIK}

Algoritma propagasi balik merupakan pengembangan dari jaringan saraf feedforward, disebut juga multilayer feedforward. Perbedaannya terletak pada penambahan lapisan tersembunyi antara lapisan masukan dan lapisan keluaran. Algoritma ini ditemukan secara terpisah oleh sejumlah peneliti, yaitu Bryson dan Ho, 1969; Werbos, 1974; Parker, 1985, dan Rumelhart, Hinton \& William, 1986 [10].

Piranti lunak yang dikembangkan, menerapkan arsitektur propagasi balik dengan tiga lapisan. Arsitektur multilayer feedforward JST dengan tiga lapisan sudah cukup untuk digunakan dalam pengklasifikasian, dimana satu lapisan tersembunyi cukup untuk mengaproksimasi suatu fungsi kontinu $[10,11]$ menyatakan bahwa dalam pattern recoginition, jika jumlah neuron dalam lapisan tersembunyi lebih sedikit atau sama dengan jumlah neuron pada lapisan masukan, maka JST tidak cukup baik menentukan batasan klasifikasi keluaran. Simpul pada lapisan tersembunyi dapat ditambahkan satu demi satu dalam eksperimen [12] sehingga dalam uji coba dilakukan pengaturan terhadap jumlah simpul pada tiap lapisan yang dapat menghasilkan sebuah JST dengan kinerja optimal.

Arsitektur propagasi balik JST yang dirancang untuk aplikasi ini dapat diilustrasikan seperti pada Gambar 3 .

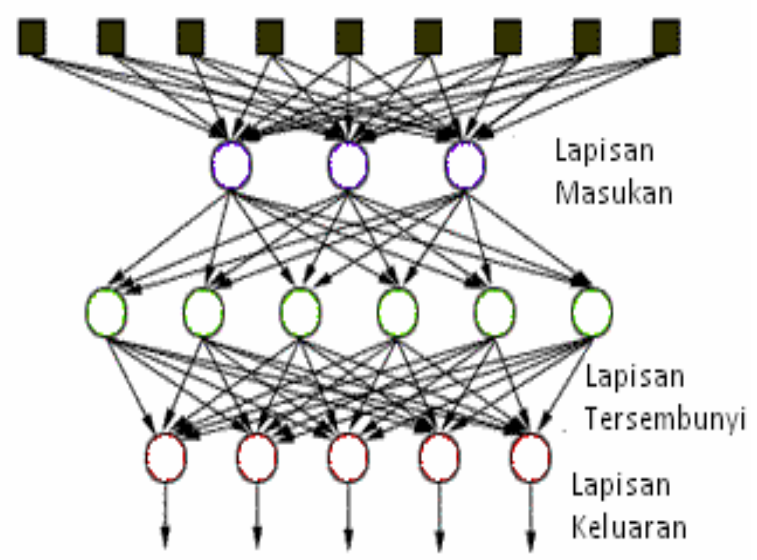

Gambar 3. Arsitektur Propagasi Balik dengan 3 Lapisan (Layer)
Proses pelatihan JST dengan algoritma propagasi balik memerlukan tiga tahapan [13], yaitu feedforward data masukan untuk pelatihan, propagasi balik untuk nilai kesalahan serta penyesuaian nilai bobot tiap simpul masing-masing lapisan pada JST. Diawali dengan feedforward nilai masukan, tiap masukan unit ke- $i\left(x_{i}\right)$ menerima sinyal input yang akan dipancarkan ke lapisan tersembunyi $Z_{1}, \ldots, Z_{p}$. Selanjutnya simpul tersembunyi ke-j akan menghitung nilai sinyal $\left(z_{j}\right)$, yang akan dipancarkan ke lapisan keluaran, menggunakan fungsi aktifasi $f$,

$$
\begin{aligned}
& Z_{j}=\theta_{l j}+\sum_{i} x_{i} v_{i j} \\
& \text { dan } \\
& z_{j}=f(Z j) .
\end{aligned}
$$

dimana $\theta_{l j}=$ bias unit tersembunyi ke-j. Nilai bias dan bobot awal dapat diambil secara acak. Tiap unit keluaran ke- $k\left(Y_{k}\right)$ lalu menghitung nilai aktifasinya $\left(y_{k}\right)$,

$$
\begin{aligned}
& Y_{k}=\theta_{2 k}+\sum_{j} z_{k} w_{j k} \\
& \text { dan } \\
& y_{k}=f\left(Y_{k}\right) .
\end{aligned}
$$

dimana $\theta_{2 k}=$ bias unit tersembunyi ke- $k$.

Selama pelatihan, pengaturan terhadap sejumlah parameter dilakukan agar kinerja JST optimal. Jumlah simpul dalam lapisan tersembunyi, parameter pembelajaran, dan juga kriteria penghentian proses pembelajaran merupakan faktor yang mempengaruhi JST [14].

Karakteristik yang harus dimiliki oleh suatu fungsi aktifasi, yaitu kontinu, differensiabel dan monoton menurun. Salah satu fungsi aktifasi yang sering digunakan adalah fungsi sigmoid yang memiliki range $(0,1)$,

$$
f(x)=\sum_{i} \frac{1}{1+\exp (-x)}
$$

dimana simpul pada lapisan keluaran akan memiliki nilai antara 0-1.

\section{ANALISIS DAN RANCANGAN PERANGKAT LUNAK}

Sistem untuk klasifikasi bentuk lengkung gigi dibangun berbasiskan JST dengan algoritma propagasi balik.

Untuk menentukan fitur lengkung gigi yang akan digunakan sebagai masukan JST, terlebih dahulu dilakukan uji statistik. Uji hipotesis dilakukan untuk mengetahui peran ukuran gigi dan dimensi lengkung gigi terhadap bentuk lengkung gigi. Pengujian dilaku- 
kan dengan uji ordered logistik yang mengkombinasikan variabel dimensi lengkung gigi sebelum dan sesudah perawatan. Hasil pengujian (Tabel 1) menunjukkan bahwa variable tinggi kaninus, intermolar, interkaninus, dan tinggi molar mempengaruhi bentuk lengkung gigi.

Tabel 1. Hasil Uji Ordered Logistik Bentuk Lengkung Gigi

\begin{tabular}{lcccccc}
\hline Variabel & Koefisien & S.E & $\mathbf{Z}$ & $\mathbf{P}$ & $\begin{array}{c}\text { [95\% selang } \\
\text { kepercayaan] }\end{array}$ \\
\hline IK sesudah & -0.586 & 0.0789 & $\mathbf{- 7 . 3 9}$ & $\mathbf{0 . 0 0 0 *}$ & -0.737 & -0.428 \\
TK sesudah & 0.967 & 0.1121 & $\mathbf{8 . 6 3}$ & $\mathbf{0 . 0 0 0}$ & 0.747 & 1.187 \\
IM sesudah & 0.194 & 0.0496 & $\mathbf{3 . 9 1}$ & $\mathbf{0 . 0 0 0}$ & 0.096 & 0.291 \\
TM sesudah & -0.142 & 0.0369 & $\mathbf{- 3 . 8 5}$ & $\mathbf{0 . 0 0 0}$ & -0.215 & -0.0697 \\
\hline
\end{tabular}

Keterangan: * $*$ p $<0,05 ; \operatorname{LR~chi}^{2}(4)=92,46 ; \operatorname{Prob}>\operatorname{chi}^{2}=0,0000$; Log likelihood $=-282,72851$; pseudo R2 $=0,1405 ; \mathrm{n}=380$; $\mathrm{S} . \mathrm{E}=$ Standard Error; $\mathrm{p}=$ perbedaan kemaknaan

Berdasarkan uji statistik untuk menentukan parameter lengkung gigi, maka ditetapkan 4 (empat) parameter yang akan digunakan sebagai fitur untuk masukan pada JST. Paramater tersebut, yaitu interkaninus, intermolar, tinggi kaninus, dan tinggi molar.

Eksperimen dilakukan dengan menggunakan sejumlah 190 data numerik dalam satuan millimeter hasil pengukuran yang dilakukan terhadap gambar model cetakan gigi rahang atas pasien sebelum dan sesudah perawatan yang didapat dengan melakukan pemindaian pada model cetakan gigi 3D (tiga dimensi) asli. Data tersebut diperoleh dari hasil ekstraksi citra model cetakan gigi yang dilakukan dengan menggunakan piranti lunak image tool. Sampel diambil secara acak terdiri dari 42 orang lakilaki $(22,1 \%)$ dan 148 orang perempuan $(77,9 \%)$ Indonesia yang menjalani perawatan ortodonti di sejumlah klinik dan praktik ortodonti di Jakarta. Parameter lengkung gigi yang diukur, yaitu interkaninus, intermolar, tinggi kaninus, dan tinggi molar. Untuk mengurangi kesalahan pengukuran, maka pengukuran dilakukan sebanyak tiga kali, lalu diambil nilai rata-ratanya untuk kemudian digunakan sebagai data sampel. Sebanyak $40 \%$ dari data sampel digunakan untuk pelatihan JST, dan $60 \%$ digunakan untuk pengujian. Dalam pengembangannya, sistem dirancang dengan menggunakan MATLAB 7.0.

Eksperimen diawali dengan merancang sistem piranti lunak pengklasifikasi bentuk lengkung gigi yang terdiri dari sejumlah fitur pendukung seperti ditunjukkan pada Gambar 4 .

Arsitektur propagasi balik yang dirancang dalam eksperimen terdiri dari tiga lapisan. yaitu lapisan masukan yang terdiri dari empat simpul sedangkan lapisan keluaran terdiri dari tiga unit dimana fungsi sigmoid digunakan sebagai fungsi aktifasi pada semua lapisan dalam JST. Berikutnya, eksperimen dilanjutkan dengan pelatihan JST. Sejumlah 76 data dilatih pada JST dengan menggunakan jumlah simpul pada lapisan tersembunyi, epoch dan learning rate yang berbeda. Indikator yang digunakan untuk mengukur keberhasilan arsitektur dalam eksperimen ini yaitu persentase jumlah lengkung yang berhasil diklasifikasikan dengan benar oleh JST. Nilai bias dan bobot awal untuk algoritma propagasi balik diambil secara acak, sedangkan bobot akhir pada lapisan keluaran digunakan untuk menentukan bentuk lengkung gigi apakah ovoid, tapered atau square.

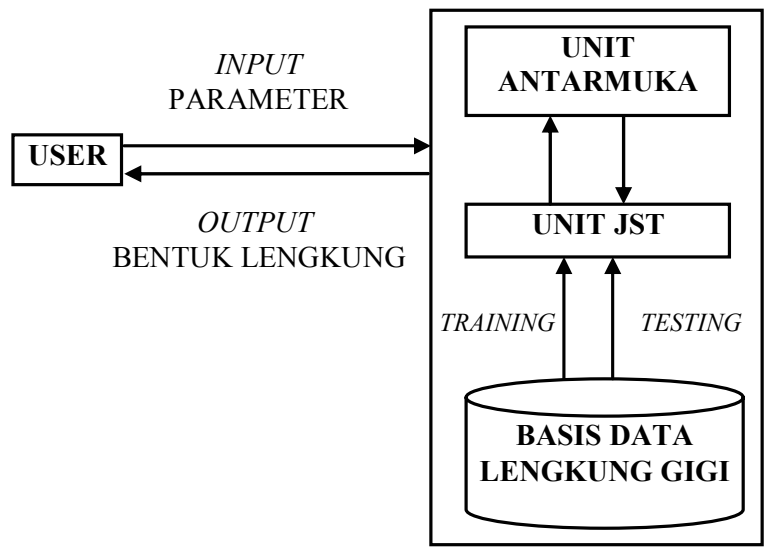

\section{Gambar 4. Rancangan Sistem Piranti Lunak}

Proses pelatihan JST dilakukan hingga kesalahan mencapai 0.001 atau hingga jumlah epoch tercapai. Setelah tahap pelatihan, dilanjutkan dengan tahapan pengujian. JST diuji dengan mengunakan 114 data sampel lengkung gigi. Hal ini dilakukan untuk mengevaluasi seberapa besar kemampuan JST yang dirancang dapat mengklasifikasikan bentuk lengkung gigi dengan tepat.

\section{HASIL}

Sistem aplikasi yang dibangun dengan tampilan seperti pada Gambar 5, terdiri dari sejumlah fitur, yaitu pelatihan (training), pengujian (testing), dan pengenalan (recognizing). Fitur training digunakan untuk pelatihan JST yang telah dirancang, testing sebagai fitur untuk pengujian guna evaluasi sistem aplikasi, dan recognizing untuk memprediksi bentuk lengkung sebuah lengkung gigi setelah menjalani perawatan. Gambar 5 menunjukkan antarmuka untuk training dan testing sedangkan Gambar 6 dan Gambar 7 mengilustrasikan antar muka sistem untuk mengenali bentuk lengkung berdasarkan sejumlah nilai parameter yang dimasukkan oleh pengguna. Proses pengaturan terhadap parameter jumlah epoch, 
learning rate, dan maximum error juga dilakukan selama uji coba guna mendapatkan JST dengan kinerja yang optimal. Setelah dilakukan uji coba, diperoleh JST dengan kinerja yang optimal dengan arsitektur yang terdiri dari sejumlah parameter dengan nilai seperti direpresentasikan pada Tabel 2 .

Tabel 2. Topologi JST

\begin{tabular}{ll}
\hline Parameter & Nilai \\
\hline Jumlah Simpul Masukan & 4 \\
Jumlah Simpul Keluaran & 3 \\
Jumlah Simpul Tersembunyi & 5 \\
Jumlah Lapisan Tersembunyi & 1 \\
Learning Rate & 0.1 \\
Epoch & 1000 \\
Maximum Error & 0.1 \\
\hline
\end{tabular}

Pengujian terhadap performa JST yang telah didapat dilakukan sebanyak 20 kali untuk melihat kestabilan hasil yang didapat. Selama uji coba terdapat perbedaan nilai persentase keberhasilan pengklasifikasian bentuk lengkung oleh JST. Hal ini disebabkan nilai sejumlah parameter secara acak oleh MATLAB tiap proses pelatihan dan pengujian dilakukan. Hasil uji coba tersebut direpresentasikan pada Tabel 3 .

Tabel 3. Hasil Uji Coba

\begin{tabular}{cc}
\hline $\begin{array}{c}\text { Persentase Hasil } \\
\text { Pengujian }\end{array}$ & $\begin{array}{c}\text { Jumlah keberhasilan pengujian } \\
\text { ( per 20 kali) }\end{array}$ \\
\hline 64 & 1 \\
68,4 & 1 \\
75 & 1 \\
76,3158 & 17 \\
\hline
\end{tabular}

Dari hasil ini diketahui bahwa JST sudah cukup baik memprediksi bentuk lengkung dengan nilai yang cukup stabil dimana angka keberhasilan 76,3158\% berhasil dicapai sebanyak 17 kali (85\%). Namun, ada sebesar 23,6842\% kesalahan klasifikasi bentuk lengkung oleh JST. Setelah dianalisis, ternyata bentuk tapered dan square salah diklasifikasikan sebagai ovoid.

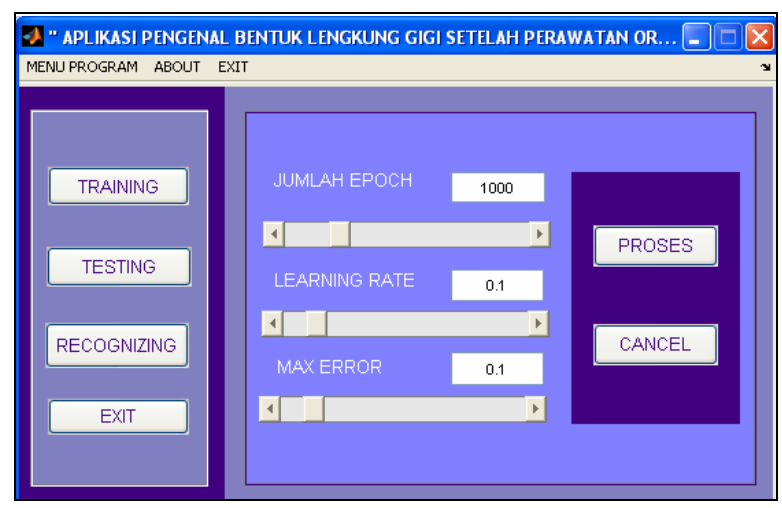

Gambar 5. Tampilan 1 antar Muka Sistem Aplikasi

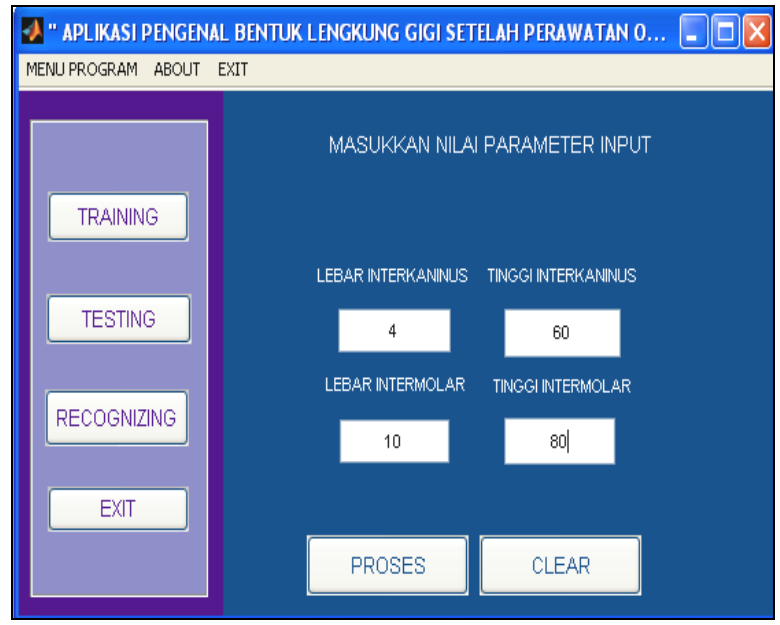

Gambar 6. Tampilan 2 antar Muka Sistem Aplikasi

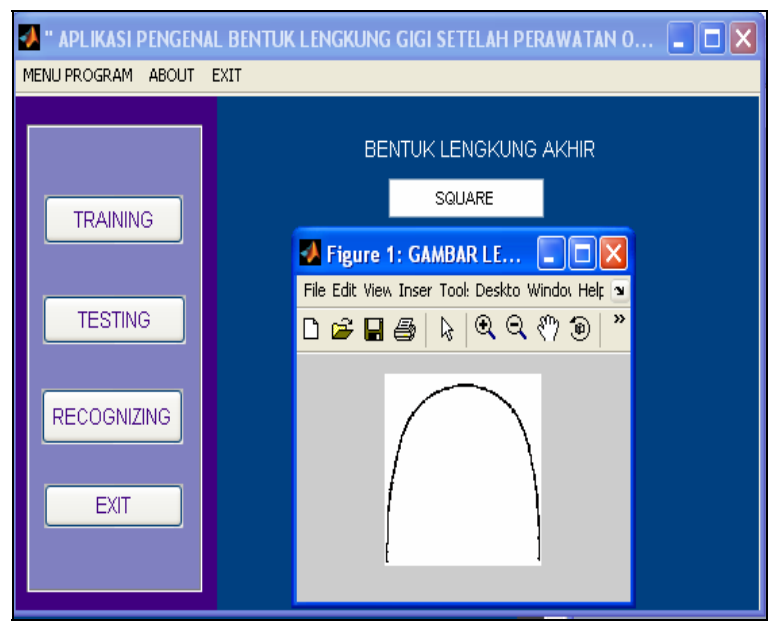

Gambar 7. Tampilan 3 antar Muka Sistem Aplikasi

Untuk melihat seberapa besar kedekatan antar data sampel yang menyebabkan kesalahan klasifikasi oleh JST, maka dilakukan analisis multivariate varians (MANOVA) yang mengubah data empat dimensi menjadi dua dimensi (ditunjukkan pada Gambar 8).

Gambar 8 menggambarkan sebaran data yang menunjukkan kedekatan karakteristik data. Dari Gambar 8 dapat dilihat bahwa titik yang menunjukkan data tepered dan square berimpit serta terkelompok sangat dekat dengan ovoid. Hal inilah yang menyebabkan kesalahan klasifikasi oleh JST dimana data tapered dan square diklasifikasikan sebagai ovoid yang memang lebih mengelompok. Selain itu, sedikitnya jumlah data sampel untuk bentuk tapered dan square mungkin menjadi faktor yang mempengaruhi klasifikasi bentuk lengkung. 


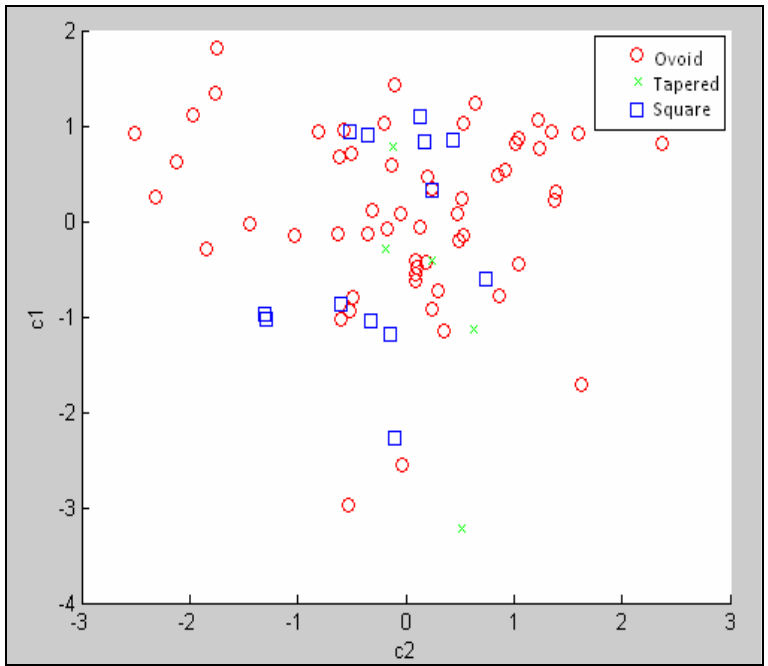

Gambar 8. Kedekatan Karakteristik Data Sampel

\section{KESIMPULAN}

Sistem aplikasi pengklasifikasi bentuk lengkung gigi dibangun dengan algoritma JST propagasi balik. yang terdiri dari lapisan masukan, satu lapisan tersembunyi, dan lapisan keluaran. Sistem ini dirancang untuk dapat mengenali ketiga bentuk lengkung gigi, yaitu ovoid, tapered, dan square yang memiliki kemiripan bentuk yang sangat tinggi. Parameter untuk masukan JST dipilih berdasarkan hasil uji statistik untuk menentukan parameter apa saja yang mempengaruhi bentuk lengkung gigi. Dari hasil uji tersebut, diketahui 4 (empat) parameter yang terbukti mempengaruhi bentuk lengkung, yaitu interkaninus, intermolar, tinggi kaninus, dan tinggi molar.

JST propagasi balik yang telah dirancang lalu dilatih dan diuji dengan menggunakan sampel data numerik hasil pengukuran terhadap citra model cetakan gigi rahang atas pasien sebelum dan sesudah menjalani perawatan ortodonti. Hasil eksperimen menunjukkan bahwa JST dengan baik dapat mengenali bentuk lengkung gigi sebesar 76,3158\%. Nilai ini adalah nilai optimum yang dapat dicapai setelah tuning terhadap sejumlah paremeter JST dilakukan. Pengulangan terhadap uji coba yang dilakukan sebanyak 20 kali untuk arsitektur yang dirancang, menunjukkan angka yang sama besar dan cukup meyakinkan. Sebanyak 17 kali pengujian menghasilkan angka persentase keberhasilan yang sama.

Hasil uji coba tersebut menunjukkan bahwa JST propagasi balik dapat digunakan untuk mengenali bentuk lengkung gigi untuk keperluan diagnosis sebagai dasar perencanaan perawatan ortodonti. Namun, masih terdapat sebesar $23,6842 \%$ kesalahan klasifikasi oleh JST. Hal ini disebabkan karena adanya kemiripan yang cukup tinggi antara ketiga bentuk, dimana tapered dan square diklasifikasikan sebagai ovoid. Fenomena ini dapat dilihat dari hasil analisis multivariate yang menghasilkan diagram pencar dimana untuk tapered dan square selalu berimpit dan mengelompok dengan ovoid. Sedikitnya jumlah sampel untuk square dan tapered dibandingkan ovoid kemungkinan menjadi salah satu penyebab terjadinya kesalahan klasifikasi. Kemiripan yang tinggi menunjukkan adanya kesamaran (fuzzyness) bentuk yang menyebabkan algoritma propagasi balik tidak mampu mengklasifikasikan dengan tepat bentuk sejumlah lengkung gigi. Dengan menambahkan teori fuzzy pada metode pengembangan sistem dan meningkatkan jumlah sampel data mungkin dapat menurunkan tingkat kesalahan klasifikasi.

Kinerja sistem aplikasi ini masih perlu ditingkatkan dengan memperbaiki metode pengembangan sistem, misalnya menggunakan metode klasifikasi yang berbeda antara lain SVM, metode clustering, sehingga dapat diaplikasikan di dunia nyata guna mendukung perawatan ortodonti yang efisien.

\section{DAFTAR PUSTAKA}

1. McLaughlin, Richard P., and J. C. Bennett, Arch Form Considerations for Stability and Esthetics, Rev. Esp. Orthod, Vol.29, No.2, 1999, pp. 46-63.

2. Braun, Stanley, William P. Hnat, Dana E. Fender, and Harry L. Legan. The Form of The Human Dental Arch, The Angle Orthodontist, Vol. 68, No.1, 1998, pp. 29-36.

3. Kook, Yoon-Ah, Kunihiko Nojima, Hong-Beom Moon, Richard P. McLaughlin, and Peter M. Sinclair, Comparison of Arch Forms Between Korean and North American White Populations, American Journal of Ortodontics and Dentofacial Orthopedics, Vol.126, No.6, 2004, pp. 680-686.

4. Taner, Tulin Ugur, Semra Ciger, Hakan El, Derya Germec, and Alphan Es, Evaluation of Dental Arch Width and Form Changes After Orthodontic Treatment and Retention with a New Computerized Method, American Journal of Ortodontics and Dentofacial Orthopedics, Vol.126, N0. 4, 2004, pp. 464-476.

5. Puspasari, Shinta, and M. Rahmat Widyanto, Active Learning for Predicting Dental Arch Form by Using Hybrid K-Nearest Neighbor and Quadratic Regression, Proceeding of International Conference on Instrumentation, Communication, and Information Technology, Agustus 2007.

6. Puspasari, Shinta, and M. Rahmat Widyanto, Dental Arch Form Template Extraction Using 
Quadratic Regression, Proceeding of International Conference on Instrumentation, Communication, and Information Technology, Agustus 2007.

7. Puspasari, Shinta, and M. Rahmat Widyanto, Piranti Lunak Pendukung Perawatan Ortodonti Berbasis Jaringan Saraf Tiruan, Proceeding of National Conference on Computer Science and Information Technology, Januari 2007, pp.343346.

8. Graber, Thomas M., Orthodontics, W.B. Saunders Company, Philadelphia, 1966.

9. Noroozi, Hassan, T. Hosseinzadeh Nik, and Reza Saeeda, The Dental Arch Form Revisited, Angle Orthodontist, Vol. 71, No. 5, 2001, pp. 386-389.

10. Hertz, John A., Anders Krogh, and Richard G. Palmer, Introduction to The Theory of Neural Computation, Addison Wesley, 1991.
11. Gori, Marco, and Franco Scarselli, Are Multilayer Perceptrons Adequate for Pattern Recognition and Verification?, IEEE Transaction on Pattern Analysis and Machine Intelligence, Vol. 20, No. 11, 1998, pp. 1121-1131.

12. Fujita, Osamu, Statistical Estimation of the Number of Hidden Units for Feedward Neural Networks, IEEE Transactions on Neural Networks, Vol. 11, No.5, 1998, pp. 851-860.

13. Fausett, Laurene V., Fundamental of Neural Networks: Architectures, Algorithms, Application, Prentice Hall, 1994.

14. Archer, N. P., Wang, S., Learning Bias in Neural Networks and an Approach to Controlling Its Effects in Monotonic Classification, IEEE Transaction on Pattern Analysis and Machine Intelligence, Vol. 15, No.9, 1993, pp. 1121-1131. 